\title{
Facebook in Higher Education: The UNITEC Case
}

\author{
Carlos Roberto Arias Arévalo, PhD. ${ }^{1}$ \\ ${ }^{1}$ Universidad Tecnológica Centroamericana (UNITEC), Honduras, cariasa@unitec.edu
}

\begin{abstract}
To reach our students, faculty needs to be where they can be found: online. There is no question that Internet technologies have changed the way we live, so it is obvious that there is an impact on education. Students learn differently, and furthermore they interact differently. It is imperative that education institutions recognize this reality. This paper is the result of a study made on the Universidad Tecnologica Centroamerica (UNITEC) Tegucigalpa campus to measure the penetration of Facebook in the classroom, and to explore what the usage of Facebook by UNITEC faculty and students. Results show that students are more willing than faculty to incorporate the Facebook platform to their academic life. A proposal on how to effectively use Facebook in course work will be presented, based on the findings on the experience of two years integration of Facebook in computer science courses.
\end{abstract}

Keywords—Facebook, social networks, education

Digital Object Identifier (DOI): http://dx.doi.org/10.18687/LACCEI2015.1.1.054

ISBN: 13 978-0-9822896-8-6

ISSN: $2414-6668$

$1^{\text {th }}$ LACCEI Annual International Conference: “Engineering Education Facing the Grand Challenges, What Are We Doing?” July 29-31, 2015, Santo Domingo, Dominican Republic ISBN: 13 978-0-9822896-8-6

ISSN: 2414-6668

DOI: http://dx.doi.org/10.18687/LACCEI2015.1.1.054 


\title{
Facebook in Higher Education: The UNITEC Case
}

\author{
Carlos Roberto Arias Arévalo, $\mathrm{PhD}^{1}$ \\ ${ }^{1}$ Universidad Tecnológica Centroamericana (UNITEC), Honduras, cariasa@unitec.edu
}

\begin{abstract}
To reach our students, faculty needs to be where they can be found: online. There is no question that Internet technologies have changed the way we live, so it is obvious that there is an impact on education. Students learn differently, and furthermore they interact differently. It is imperative that education institutions recognize this reality. This paper is the result of a study made on the Universidad Tecnologica Centroamerica (UNITEC) Tegucigalpa campus to measure the penetration of Facebook in the classroom, and to explore what the usage of Facebook by UNITEC faculty and students. Results show that students are more willing than faculty to incorporate the Facebook platform to their academic life. A proposal on how to effectively use Facebook in course work will be presented, based on the findings on the experience of two years integration of Facebook in computer science courses.
\end{abstract}

Keywords—Facebook, social networks, education

\section{INTRODUCTION}

Michael Wesch claims that students nowadays have changed the way that they learn [9]. The XXI century student is different from the student of the previous century, the ubiquity of the Internet, and the emergence of different services that cry for the attention of millions of users around the world, has contributed to the cultural shift that is currently being seen around the world. Students are different, and demand a different way of interaction with them, students arrive to higher education institutions empowered with technological abilities [1], but soon realize that they cannot use these capabilities since faculty and classrooms do not take advantage of them.

Current times demand that educational institutions reach out to the students, to compel them to engage in courses, to make them feel part of the class. For this purpose teachers need to go where the students are, and right now the most are online. It is a reality that young people spend several hours a day online, and some of this time is dedicated to social networks, so much that social networks are integrated into their daily practices [4]. Besides being an entertainment activity, social networking is acquiring also a variety of educational purposes along with their social use [3], so much that there has been an emergence of social network sites devoted exclusively to education.

Several studies have been done about the evolution of social networks and their usage in higher education around the world, however very little has been done in Honduras with this respect, with the exception to the work of [2]. The authors identify that the usage of social networking in education is positive and is advantageous because of the free of charge nature of these services, additionally they claim that there is a learning curve issue that needs to be addressed, specially with the faculty involved, given that faculty is usually a late adopter of technology. An education segment that would be greatly benefited is the distance learning students that would favor them in their communication. This aforementioned study was mostly based on Learning Management Systems, so there was a clear opportunity to do a study to explore the usage of social networking sites in education.

This study has the purpose of examining how students and faculty at the Universidad Tecnologica Centroamericana (UNITEC) in the Tegucigalpa campus use social network sites, to present the results of a two year long period of using Facebook in computer science courses, and to propose a methodology on the usage of Facebook to enhance the students experience at the higher education level.

The paper is organized as follows: after this introduction a brief background on social network sites is presented, after that a concise description of the methodology followed in the study. Results of the surveys and of the experiment with students are next, followed by possible venues of future research and finally, the conclusions.

\section{Social Network Sites BACKGROUND}

\section{A. Definitions}

Susan Barnes from Rochester Institute of Technology defines Social Network Sites (SNS) as Internet technologies that allow people to connect and communicate with other people that would not usually meet face to face [10]. Another definition of SNS is given by Danah Boyd: "Web based services that allow individuals to construct a profile within a bounded system, create connections with other users, browse and navigate through the connections made with friends" [8]. Clearly SNS are Web 2.0 platforms that allow people to connect with each other, where people can share plain text, pictures, links and video. Depending on the specific purpose of a given SNS the platform would have different capabilities or user segments.

\section{B. History}

The following chronology depicts the launch dates of several Social Network Sites to show their evolution through time. Facebook will be left out of this chronology as it will be presented on his own afterwards. 
Table I

Chronology of Social Network Sites [8]

\begin{tabular}{|c|c|c|}
\hline Life & SNS & Comments \\
\hline $1997-2001$ & SixDegrees.com & \\
\hline $1997-$ & AsianAve.com & Ethnic social network \\
\hline $1999-$ & LiveJournal.com & $\begin{array}{l}\text { Russian base blog like social } \\
\text { community }\end{array}$ \\
\hline $1999-$ & BlackPlanet.com & $\begin{array}{l}\text { African-American social } \\
\text { network service with dates and } \\
\text { jobs sections. }\end{array}$ \\
\hline $2000-2010$ & LunarStorm.com & Oriented to teenagers \\
\hline $2000-$ & MiGente.com & $\begin{array}{l}\text { Latino American community } \\
\text { social network }\end{array}$ \\
\hline $2001-$ & Cyworld.com & Korean social network site \\
\hline $2002-$ & Fotolog.com & Photos and pictures sharing site \\
\hline $2002-$ & Friendster.com & Currently a social gaming site \\
\hline $2002-$ & $\begin{array}{l}\text { Skyblog.com } \rightarrow \\
\text { Skyrock.com }\end{array}$ & $\begin{array}{l}\text { Born Skyblog.com and became } \\
\text { Skyrock.com in } 2007 . \text { It allows } \\
\text { the creation of blogs, and users } \\
\text { share music of their own in the } \\
\text { site }\end{array}$ \\
\hline $2003-$ & LinkedIn.com & $\begin{array}{l}\text { Business oriented social network } \\
\text { site }\end{array}$ \\
\hline $2003-$ & CouchSurfing.com & $\begin{array}{l}\text { Social network to create tourism } \\
\text { connections with locals }\end{array}$ \\
\hline $2003-$ & MySpace.com & $\begin{array}{l}\text { Music related social network } \\
\text { site. Once the largest social } \\
\text { network and most visited. }\end{array}$ \\
\hline $2003-$ & tribe.net & $\begin{array}{l}\text { Community based social } \\
\text { network site }\end{array}$ \\
\hline $2003-$ & XING.com & $\begin{array}{l}\text { Professional and job related } \\
\text { social network site }\end{array}$ \\
\hline $2003-$ & Last.FM & Music based social network site \\
\hline $2004-$ & hi5.com & $\begin{array}{l}\text { Traditional social network site, } \\
\text { was the third largest in } 2008 \\
\text { after MySpace and Facebook }\end{array}$ \\
\hline $2004-2014$ & orkut.com & $\begin{array}{l}\text { Owned by Google and popular } \\
\text { in India and Brazil }\end{array}$ \\
\hline $2004-$ & ASmallWorld.com & $\begin{array}{l}\text { Paid social network for } \\
\text { international travel connections }\end{array}$ \\
\hline $2004-$ & Flickr.com & Photo sharing online community \\
\hline $2004-2012$ & Piczo.com & Social network for teens \\
\hline $2004-$ & Mixi.jp & Japanese social network \\
\hline $2004-2009$ & dodgeball.com & $\begin{array}{l}\text { Social network that used } \\
\text { location to give the user } \\
\text { recommendations. Serviced } \\
\text { mobile devices. }\end{array}$ \\
\hline $2004-$ & Care2.com & Petition based social network \\
\hline $2004-$ & Catster.com & $\begin{array}{l}\text { Cat lover community social } \\
\text { network }\end{array}$ \\
\hline $2004-2013$ & Hyves.com & $\begin{array}{l}\text { Dutch social network, became } \\
\text { gaming site in } 2013\end{array}$ \\
\hline $2005-2013$ & 360.yahoo.com & Yahoo social network site \\
\hline $2005-$ & NING.com & $\begin{array}{l}\text { Permits the creation of online } \\
\text { communities }\end{array}$ \\
\hline $2005-$ & YouTube.com & Video sharing social network site \\
\hline $2005-$ & $\begin{array}{l}\text { Xanga.com } \\
\text { (Xanga 2.0) }\end{array}$ & $\begin{array}{l}\text { Blog bases social network, } \\
\text { currently does not accept new } \\
\text { users }\end{array}$ \\
\hline $2005-2013$ & Bebo.com & $\begin{array}{l}\text { Used to be a social network site, } \\
\text { now a social app developer }\end{array}$ \\
\hline $2006-$ & QQ.com & $\begin{array}{l}\text { Chinese social network that } \\
\text { offers music, blog and other } \\
\text { services }\end{array}$ \\
\hline $2006-2011$ & spaces.live.com & $\begin{array}{l}\text { Microsoft social network, } \\
\text { became OneDrive }\end{array}$ \\
\hline $2006-$ & Twitter.com & Microblogging social network \\
\hline
\end{tabular}

It is worthy to mention that MiGente.com and BlackPlanet.com run a very similar platform, this may be related to the fact that these two (along with AsianAve.com with a different interface) are owned by the same company: InteractiveOne.com.

The previous list [8] is not supposed to be exhaustive as several other social network sites have been created and disappeared in the time span that has been presented. This list should present enough information to show how social network sites have evolved through time, some are general purpose in their nature, most of them are free, some are paid, some are ethnic by nature, some are business and job oriented and some are for travelers. However there is one social network site that was not present in the table: Facebook. This is the most visited social network in the present, and has a history of its own. Facebook launched in February 2004, at that time it was exclusive to Harvard University students, by March it expanded to Stanford, Columbia and Yale. In May 2005 it supported 800 college networks, in September that year it added High School networks, and in October it allowed users from international school networks. It was not until September 26, 2006 that Facebook open its doors to the general public. In three months after it was open to the public it had 12 million users registered [12]. It is interesting to mention that Facebook started in the academic community and that fact created a sense of exclusivity in the communities created in this site.

\section{Facebook Statistics}

As of February 2014 Facebook reported the following statistics [12]:

- $\quad 890$ Million daily active users

- 745 Million daily active mobile users

- $\quad 1.39$ Billion monthly active users

- $\quad 82.4 \%$ of users outside of Canada and the United States

More than $83 \%$ of the users are active on mobile devices, a fact that shows how important mobile technology is to social networking and to current day way of doing business. Business Insider states that Facebook Mobile ad revenue will grow significantly during the near future [7], proving that the future of social networks will rely on mobile devices.

\section{Other Social Networks for Education}

There are many social networks that are built for education. Among them there are the Classroom from Google, Edmodo and Schoology. In the case of Google Classroom (http://classroom.google.com), it requires a Google Apps subscription from the institution, and is currently only given access to institutions with .edu top level domains. Google classroom is convenient because it integrates all Google Apps

$1^{\text {th }}$ LACCEI Annual International Conference: "Engineering Education Facing the Grand Challenges, What Are We Doing?" 
in the platform, and it helps with the assignment of homework delivery and grading, much like traditional Learning Management Systems, with the additional social network component. On the other hand there is Edmodo (http://www.edmodo.com), has a social network interface, and it allows for general comments, called notes, alerts to students, assignments delivery and grading, quiz and polls. Furthermore Edmodo has additional products like Edmodo Snapshot that helps with statistics about the students' progress, and Edmodo Mobile that helps users of the Edmodo platform to have a mobile version of the site. Unfortunately, to the date this paper was written, Edmodo Snapshot is only available in the United States. In addition to the single user accounts, Edmodo provides a tool to create work in districts that allows an expansion of the educational network, this service is offered in a free basic version and a paid premium version. Schoology (http://www.schoology.com) is another social network site for education, its free basic package includes the following features: class homepage, course profiles, flexible instructional tools to aid with differentiated instruction, badges to award students, calendar, assignment and homework management, test and quizzes, content import from Moodle, Blackboard and other LMS, mobile support, grading and rubrics for assessment, students' progress and course analytics.

\section{Methodology OF THE STUDY}

This study used several survey as instruments to recollect data. The first survey that was used was initially intended for the Online Collaborative Learning project, where a Facebook related question was added to the questionnaire asking students if they would like to integrate Facebook in their courses. This survey has been applied for eighteen months with the participation or more than 400 students of most academic programs. In addition to this survey, two different instruments were sent to all the undergraduate programs students and faculty, from which 297 students and 100 professors participated. These two surveys were mainly focused on the usage of Facebook in class work.

Besides the surveys, open interviews were conducted with students from three computer science courses to recollect qualitative data about their opinion on the use of Facebook in their courses.

Additional data was collected from the actual use of Facebook by Computer Science major students. The observation was made on their behavior on the groups created on their courses during the past two years. Factors measured were group creation date, number of current users in group, courses that used the groups (in the case that the group spanned several courses) and number of posts and comments.

\section{A. Students and Faculty Survey}

As stated in the methodology section two sets of surveys were applied. The first one related to the ongoing online collaborative learning using Wiki [5], and the instruments designed specifically for this study. The Wiki survey revealed that $30 \%$ of students would like to integrate Facebook to their academic activities. The Facebook survey revealed that $58.56 \%$ of the students like to use their Facebook account in their classes, contrasting the previous results found during the Wiki surveys.

Table II
Indicator
\begin{tabular}{|l|l|}
\hline \multicolumn{1}{|c|}{ General Overview of Results } \\
\hline Students participation & 297 \\
\hline Professors participation & 99 \\
\hline Gender distribution & 50.34 male, 49.66 female \\
\hline Age range & $16-39$ \\
\hline Students that have a Facebook account & $94 \%$ \\
\hline $\begin{array}{l}\text { Students that use Facebook for academic } \\
\text { activities }\end{array}$ & $46 \%$ \\
\hline $\begin{array}{l}\text { Students that use Facebook in their courses that } \\
\text { would like to integrate Facebook in their } \\
\text { academic work }\end{array}$ & $72 \%$ \\
\hline Faculty with Facebook account & $85 \%$ \\
\hline $\begin{array}{l}\text { Faculty with Facebook account that use } \\
\text { Facebook in their courses }\end{array}$ & $21 \%$ \\
\hline Students that share resources on Facebook & $86.55 \%$ \\
\hline Students that have smartphone & $95 \%$ \\
\hline Faculty that have smartphone & $96 \%$ \\
\hline Students that favour Facebook vs. Moodle & $67.89 \%$ \\
\hline
\end{tabular}

In the Wiki survey, students of the following majors stated they would like to use Facebook in their course work: Architecture, Communications and Advertising, Computer Science, International Relations, Psychology, and Tourism Company Management. Results differed to the survey made for the purposes of this study, the majors that most liked to use Facebook in their classes were: Civil Engineering, Communications and Advertising, Computer Science, Finances, and Graphic Design. It was expected that Computer Science students like to use online resources for their class work, this also applies to Communications and Advertising, where students are asked to analyse advertisement and to make Facebook pages to experiment customer attraction. $77.19 \%$ of students discuss academic material through Facebook, except Marketing and Tourism Management major students.

Most educational oriented social networks encourage private groups for the courses, this is consistent with the result that $89.08 \%$ of students prefer private groups for their course work in Facebook.

\section{RESULTS}

$1^{\text {th }}$ LACCEI Annual International Conference: "Engineering Education Facing the Grand Challenges, What Are We Doing?" 


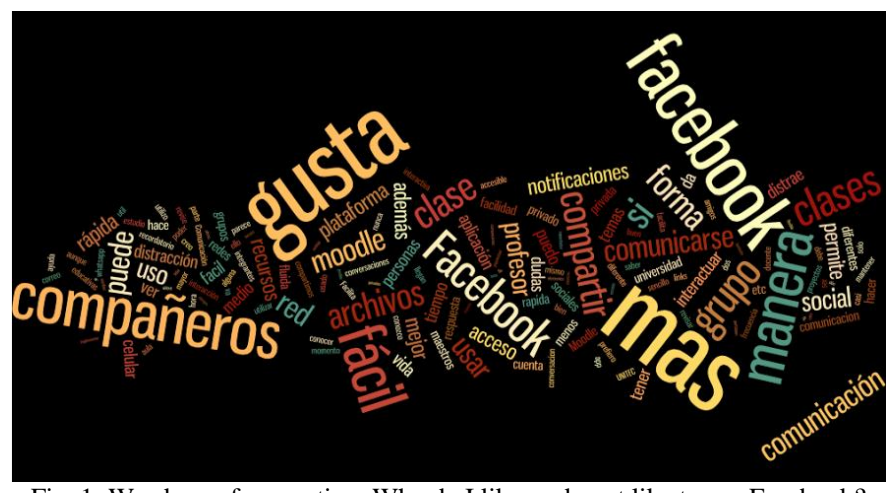

Fig. 1: Word map for question: Why do I like or do not like to use Facebook?

From the open questions to students it was found that they prefer to use Facebook instead of Moodle for communication since Facebook is much simpler and user friendlier. Another frequent comment was about the Facebook mobile app that allowed for almost instantaneous interaction with posts on Facebook. Facebook is convenient to share resources and easier to connect to other classmates were other comments. On the other hand, some of the negative comments were that some students do not like to share their personal life with their teachers, and that Facebook was a platform for social and private matters.

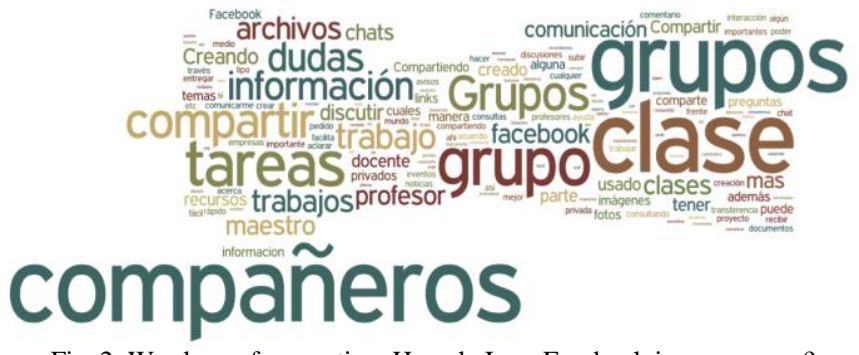

Fig. 2: Word map for question: How do I use Facebook in my courses?

Another open question revealed how students are currently using Facebook in their courses. The most frequent answers were: to share resources and information, to ask and answer questions, finally to use Facebook groups. Some students said that they use it for real time interaction with their instructors and to share results of homework exercises. In addition to the Facebook strictly related issues it was found that students also like to use the WhatsApp service to create groups for course related activities.

Faculty, on the other hand, had two open questions, the first one directed to the professors that did not have a Facebook account as to why they do not. Answers to this question circled around security, lack of usefulness and lack of interest to make an account. The second question was to the professors that do not use Facebook in their courses, to see why they do not, most frequent answers were that some do not like to mix personal matters with students, and that there is an official platform in the university for communicating with students that they do not see the need to use an additional way to communicate with students. Some said that Facebook is not for academia or for educational purposes. These results are aligned to the findings of [1] where he states that $53.2 \%$ of the faculty thinks that Facebook is for personal and social purposes and not for education.

In general, results show a better attitude to use Facebook in academics from the students than from the faculty. When asked if their experience with Facebook in their classwork was positive $78 \%$ of the students felt it was. Figure 3 shows detailed results by major.

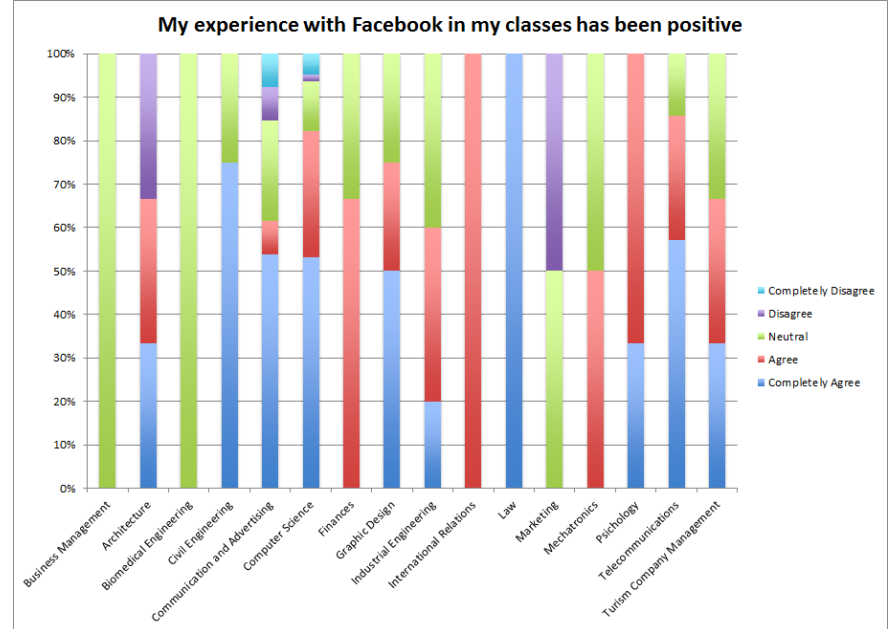

Fig. 3: Results by major on the perception whether the experience using Facebook in classwork was positive or not

\section{B. Facebook Usage in Computer Science Courses}

Facebook has been used in certain computer science courses that the author teaches. These courses are: Programming I (CCC104), Programming III (CCC208), Data Structures (CCC301), File Structures (CCC302), Programming IV (CCC205) and Theory of Computation (CCC408). Facebook usage started in January 2013 and has continued to this date.

For this purpose, Course Groups have been created, and since some courses follow the others sometimes the same group has been used in the next course. There have been instances where the groups span to courses not taught by the author of this study.

Figure 4 shows how students participate in each of the courses, notice the number next to the course code, this number represents the group number or cohort number. For instance the two courses CCC208 and CCC 301 that have number 1 mean that it is a single group that changed name once students passed from one course to the other. Notice in the figure that students did not have participation in Group 2 CCC301 and CCC302; this was due to little encouragement

13 $^{\text {th }}$ LACCEI Annual International Conference: "Engineering Education Facing the Grand Challenges, What Are We Doing?" July 29-31, 2015, Santo Domingo, Dominican Republic 
to use Facebook during that semester. In addition to those low values, there are another two semesters that show a significant decrease in participation: Group 6 CCC303 and CCC304, and Group 7 CCC303 and CCC304. These semesters represent groups in which the instructor was not even a part of the Facebook group, which reflected in the use of Facebook by students. This can be contrasted in Figure 5 that shows how instructors participate. Observe that most participation is in the form of contributions.

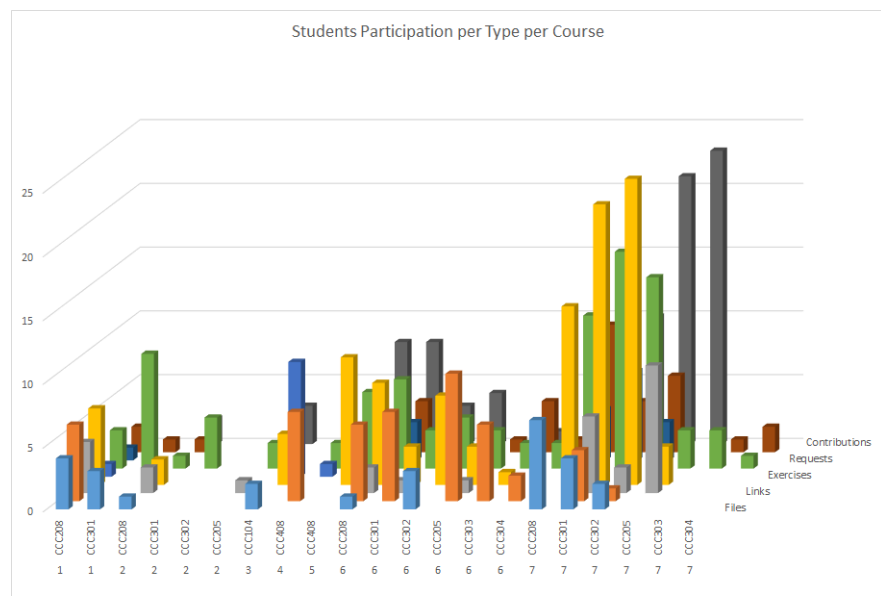

Fig. 4 Graph showing how students participated during several courses

Unlike the results found by [3] that most students do not use Facebook for academic work, UNITEC computer science students seem more likely to integrate Facebook in their class work, even though there were no grade points offered for this participation.

Professor Participation per Type per Course

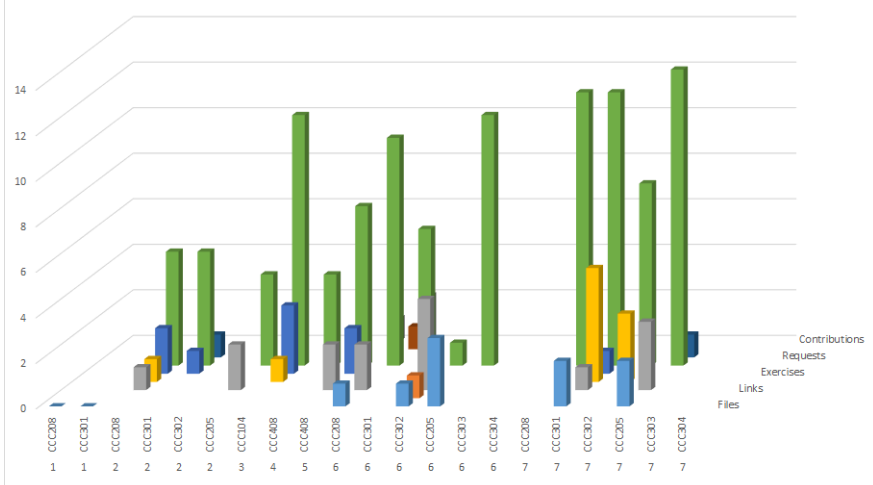

Fig. 5: Graph showing the professor participation in the Facebook groups

It was seen during these past two years that students that failed to participate in the Facebook discussions, or were not present in Facebook at all, usually had the lowest grades at the end of the term.

\section{FUTURE RESEARCH}

This study has revealed some possible paths for future research. Since most students are already using the Facebook social network platform, the next logical step would be to integrate it into academic activities in a systematic manner, in such a way that further measure on the usage is possible. To achieve this in the future, there should be a tighter integration between the Moodle LMS and Facebook, so that events in one are reflected in the other and that moving from one to the other becomes a fluid action.

Another possible venue of research is the integration to the ongoing online collaborative learning using wiki project, where students that make a contribution on their wiki page notify the rest of the group on Facebook.

Furthermore there should be an exploration of the possibility of developing Facebook Apps that help faculty and students with the integration of Facebook to course work. The most important module that should be developed is the grading application that helps faculty summarize the participation of their students in the Facebook groups.

All related research on this topic should be directed on how to improve students' engagement in their courses and how to get further involvement of the students in their process of acquiring an education that will be adapted to their reality. This should be a continuous research topic as changes in technology and culture are prone to happen faster every year, and institutions should cope with these changes for the benefit of the students.

A different line of research could be explored, to verify whether students and faculty would be willing to use an additional platform that is more academic oriented like Edmodo or Schoology.

\section{CONCLUSIONS}

This study showed that students are more open to the usage of social network sites for their academic use than faculty, it is believed that this is due to the nature of current students that were born in the Internet era.

To achieve greater participation of the students in social network sites, the presence of the instructor is preferred, in such way that he participates in the discussions that may be even started by him. Results show that greater instructor participation increases the student involvement. Moreover, students benefit from the discussion and by sharing course related material through the platform where they already login every day. This would result in better communication and strengthening of bonds between students and faculty [11] It is an interesting characteristic that students that do not participate in the discussions get lower grades, this may be a

$1^{\text {th }}$ LACCEI Annual International Conference: "Engineering Education Facing the Grand Challenges, What Are We Doing?" 
consequence of the observed "offline" isolation of these students that is reflected in their academic performance, Facebook might help isolated students get along with their classmates better; however, so far there is no evidence of this.

The experience during this study has shown that to achieve better academic results, faculty using social network sites should follow the same good practices that are used to prepare courses, but applied to online activities:

- Deeper understanding of the platform, its usage, advantages and disadvantages. For instance everyone involved should be aware of the privacy issues and how to overcome them.

- Preparation of the activities to be executed on the platform, this includes informing the students what they need to do and how they are going to be evaluated.

- Systematic evaluation of the activities, and constant feedback to the students on the platform.

- It is better to use private groups as this makes students feel more comfortable and allows for notification when something is posted in the group. Facebook pages do not have this behavior.

New technologies will continue to appear, as a consequence, there will be more cultural changes, and this will change the students that universities are going to enroll in the future. Institutions should have a clear mechanism to adapt to this reality, where the faculty development department (or equivalent) is always up to date with the state of the art developments and trends in culture [6] and technology. This permanent update will help provide constant training to faculty so it will be able to endure the changes of time, since traditional teaching is not authentic to students anymore, they do not learn like before [10]. The goal after all, is to provide meaningful education to the students, and to reach them, faculty needs to speak their language and meet them in their environment.

\section{REFERENCES}

[1] M. D. Roblyer, M. McDanel, M. Webb, J. Herman and J. V. Witty, "Findings on Facebook in Higher Education: A comparison of college faculty and student uses and perceptions of social networking sites," Internet and Higher Education, pp. 134-140, 2010.

[2] M. J. Aguilar Romero and J. L. Rodríguez García, "Redes Sociales como Apoyo a la Educación Superior en América Latina: Caso Particular Tegucigalpa Honduras," Revista Económica y Administración, pp. 83$102,2013$.

[3] M. Akyildiz and M. Argan, "Using online social networking: Students' purposes of Facebook usage at the University of Turkey," Journal of Technology Research, 2012.

[4] H. Bicen and N. Cavus, "The most preferred social network sites by students," Procedia - Social and Behavioral Sciences, pp. 5864-5869, 2010.

[5] C. R. Arias, "Implementation of Online Collaborative Learning using
Wiki," in Proceedings of the 11th Latin American and Caribbean Conference for Engineering and Technology, Cancun, Mexico, 2013.

[6] A. Lipsman, "Social Networking Explodes Worldwide as Sites Increase their Focus on Cultural Relevance," comScore, 12 August 2008. [Online]. Available: http://www.comscore.com/Insights/Press-

Releases/2008/08/Social-Networking-World-Wide. [Accessed 12 February 2015].

[7] L. O'Reilly, "Facebook's Mobile Ad Revenue Will Completely Dwarf Its Desktop Revenue Next Year," Business Insider, 21 January 2015. [Online]. Available: http://www.businessinsider.com/emarketer-2016facebook-mobile-revenue-and-mobile-user-estimates-2015-1. [Accessed 12 February 2015]

[8] D. M. Boyd and N. B. Ellison, "Social Network Sites: Definition, History and Scholarship," Journal of Computer-Mediated Communication, pp. 210-230, 2008

[9] M. Wesh, "A Vision of Students Today," Manhattan, 2007.

[10] S. Karlin, "Examining How Youths Interact Online," Education Digest, p. 6, December 2007.

[11] A. Hewitt and A. Forte, "Crossing Boundaries: Identity Management and Student/Faculty Relationships on the Facebook," in Proceedings of Computer Supported Cooperative Work 2006, Banff, Alberta, Canada, 2006.

[12] Facebook, "Company Info | Facebook Newsroom," Facebook, 2015. [Online]. Available: http://newsroom.fb.com/company-info/. [Accessed 14 February 2015].

13 $^{\text {th }}$ LACCEI Annual International Conference: "Engineering Education Facing the Grand Challenges, What Are We Doing?" 